\title{
Steady declining trend of groundwater table and severe water crisis in unconfined hard rock aquifers in extended part of Chota Nagpur Plateau, India
}

\author{
Biswajit Bera $^{1} \cdot$ Pravat Kumar Shit $^{2} \cdot$ Nairita Sengupta $^{3} \cdot$ Soumik Saha $^{4} \cdot$ Sumana Bhattacharjee $^{5}$
}

Received: 30 June 2021 / Accepted: 23 November 2021 / Published online: 7 February 2022

(c) The Author(s) 2022

\begin{abstract}
Scarcity of groundwater is a severe problem in this region due to over exploitation of groundwater from unconfined hard rock aquifers. The main objectives of this study are to analyse the spatiotemporal variability and fluctuation of groundwater table and to predict the location of groundwater depression pockets. Total 21 consecutive years (1996-2017) groundwater monitoring well data (pre- and post-monsoon) have been collected from CGWB, Government of India. The nonparametric Mann-Kendall trend analysis and standardized precipitation index (SPI) have been applied to detect the trend of groundwater level and rainfall variability, respectively. Exponential smoothing has also been fitted for future prediction. The pre- and post-monsoon results (1996-2017) showed that around 77\% (22 stations) and 78\% (23) monitoring stations were indicating declining trend of groundwater table at the rate of -0.006 to $-0.205 \mathrm{~m} / \mathrm{year}$ and -0.005 to $-0.192 \mathrm{~m} / \mathrm{year}$, respectively. Similarly, future (2040) groundwater depression result predicted that around 75\% (21) stations, the groundwater table will be depleted above $5 \mathrm{~m}$ during pre-monsoon while about 53\% (16 stations) monitoring wells, the groundwater table will be fallen above $5 \mathrm{~m}$ during post-monsoon. Consequently, around 52\% (15) and 50\% (14) stations are being faced groundwater drought in the recurrent interval of above 2 years during pre-monsoon and post-monsoon, respectively. Driving factors of water table depletion are huge withdrawal of groundwater for dry farming and reduction of recharge areas due to rapid land use modification. The uniqueness of this study exhibits the nature of declining trend of groundwater table and identification of depression pockets.
\end{abstract}

Keywords Groundwater table fluctuation $\cdot$ Mann-Kendall trend analysis $\cdot$ Standardized precipitation index $\cdot$ Pre- and postmonsoon

Sumana Bhattacharjee

sumana.aarohi@gmail.com

Biswajit Bera

biswajitbera007@gmail.com

Pravat Kumar Shit

shitpravat2013@gmail.com

Nairita Sengupta

nairitasengupta2@gmail.com

Soumik Saha

soumiksaha577@gmail.com
2 PG Department of Geography, Raja Narendralal Khan Women's College (Autonomous), Vidyasagar University, Midnapore 721102, India

3 Department of Geography, Diamond Harbour Women's University, Sarisha 743368, India

4 University of Calcutta, 35, Ballygunge Circular Road, Kolkata 700019, India

5 Department of Geography, Jogesh Chandra Chaudhuri College (University of Calcutta), 30, Prince Anwar Shah Road, Kolkata 700 033, India

1 Department of Geography, Sidho-Kanho-Birsha University, Ranchi Road, P.O. Purulia Sainik School, Purulia 723104, India 


\section{Introduction}

In the recent years, excessive stress on groundwater resource is due to unexpected population growth along with urban and rural infrastructural development. This indispensable natural renewal resource can sustain the whole biota of the earth system and fortunately, this renewal resource which is automatically recharged through precipitation. Different geological structures such as fault, joint, bedding, cleavage, fracture, foliation and lineaments have the ability to transmit and store the groundwater through the porous, saturated water bearing and water holding aquifer (Nilsen et al. 2003; Basu and Bera 2010). In the present era, groundwater crisis has become a global concern and the magnitude and frequency of groundwater vulnerability have been tremendously increased (Halder et al. 2020). Groundwater is the significant source of drinking water in various parts of India particularly in arid and semi-arid regions. In India, total 50\% irrigated land depends on groundwater irrigation and it leads overexploitation of this precious natural resource in different parts of our country (CWC 2006). Groundwater is the cleanest and purest form of water resource, and it meets the overall demand of the biosphere. So, a sustainable use of this natural resource should be maintained in various parts of the world (Assaf and Saadeh 2009).

The principal causes of groundwater table depletion for shallow unconfined aquifers are the unscientific exploitation of groundwater resource for industry, agriculture, drinking and other domestic purposes (Thakur and Thomas 2011). The use of groundwater has been augmented approximately $300 \%$ by different socio-cultural activities since 1950s (Doll et al. 2012). The groundwater quality is very much dependent over the aquifer characteristics, materials and permeability (Bera 2010). The fluctuation of groundwater table is a time-dependent stochastic phenomenon which varies mainly inflow, outflow and through flow of the aquifer system (Bera 2010). The height of the groundwater table is an illustration of the hydrological system, transmissivity and the hydraulic conductivity of the aquifer system of an area (Thakur and Thomas 2011; Bera 2010). In India, most of the rainfall occurs in the monsoon season and the variability of monsoon rainfall is a crucial factor behind the fluctuation of groundwater table (Hanson et al. 2004; Bera 2010). The consequence of groundwater fluctuation, depletion and the groundwater shortage over an area is termed as groundwater drought which has a significant negative effect on agriculture, industry, domestic and mainly drinking purposes (Bloomfield and Marchant 2013; Bera et al. 2021b).

Since the last few decades, groundwater extraction is being increased tremendously around the globe and the major consumers of groundwater are developing countries of south and south-east Asia such as India, Bangladesh,
Pakistan and China due to its high growth rate of population (Gun 2012). According to the report of central groundwater board (2017-2018) in India, groundwater extraction had increased around 62-63\% and the most over-exploited regions are Delhi, Punjab and Haryana due to its high agricultural and economic activities. Around $60 \%$ of the wells in India showed a declining trend of groundwater table for hydrological drought (CGWB 2017-2018). A continuous declining trend of groundwater quality is a great concern among different parts of India. Groundwater quality has been affected by domestic, industrial and agricultural contaminants. The groundwater table fluctuation was also analyzed over Netherland and a declining trend of groundwater table was observed in an extensive area due to drought and extensive unscientific exploitation by the farmers (Gehrels et al. 1994). In West Bengal particularly in Bankura, Purulia, Paschim Medinipore districts have faced declining trend of water table. Subsequently, Purulia district (an extended part of Chota Nagpur Plateau) is popularly known as a water scarcity and drought prone district of West Bengal (Bera et al. 2021b). The scarcity of water in this region is not only because of uncontrolled use of groundwater but also unfavourable geo-hydrological characteristics of this hard rock terrain (Bera and Ghosh 2019). Fluctuation of groundwater level is not always related with rainfall and drought characteristics; sometime it is highly correlated with poor management, improper planning and policy (Pophare et al. 2014). Purulia district is an extended part of Chota Nagpur gneissic complex of Singhbhum Protocontinent and groundwater is mainly restricted within diverse structural units such as fault, lineament, joints and fractures (Bera and Ghosh 2019). The intersection of different linear structures or the shear zones is considered as a favourable condition for groundwater storage (Cook 2003). When the fault lies perpendicular to the flow direction of groundwater, then the groundwater is channelized along the perpendicular fractures and it helps for groundwater storage. This kind of landforms can accelerate the level of permeability (Babiker and Gudmundsson 2004). Geo-statistical methods are the important tools for analysis of the spatiotemporal variability, interpolation between various points or principal values and generate the maps associated with error statistics (Zhou et al. 2011). Recently, various geo-statistical methods are extensively used to predict the spatial variability of groundwater quality and availability (Nazari Zade et al. 2006). The trend detection of groundwater level in a time series can be estimated by different statistical methods such as linear regression analysis, Mann-Kendall test, different high accuracy parametric and nonparametric methods (Mantegna and Stanley 2000). Mann-Kendell test is a nonparametric test which has been considered as a robust statistical trend analysis method in a time series data and it does not require any particular or normal distribution of the dataset (Yang et al. 2004; Mondal 

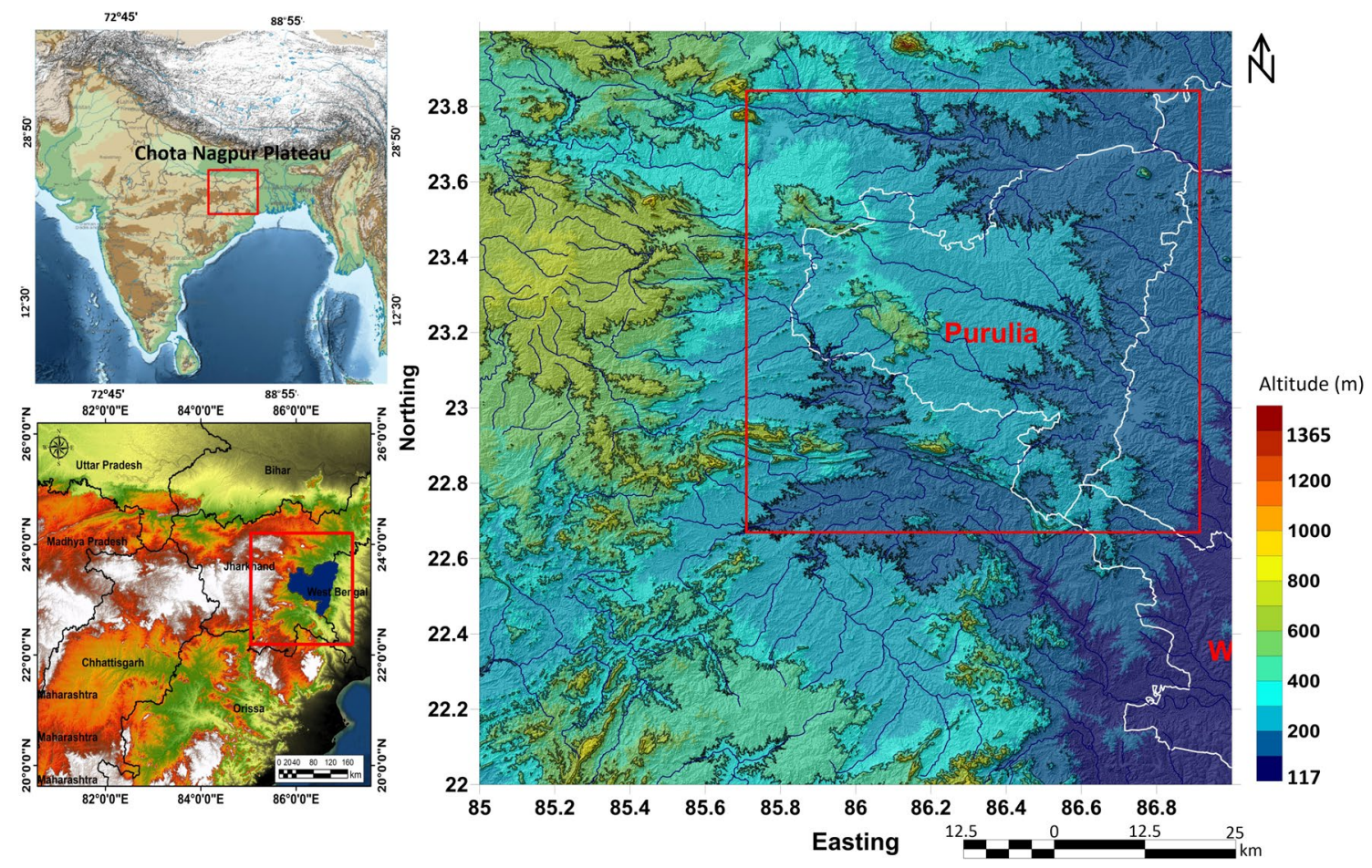

Fig. 1 Geographical location of the study area

et al. 2012). Different geo-statistical approaches have been considered for mapping of groundwater level, fluctuation and identify the trend dynamicity of groundwater (Mini et al. 2014). This scientific study will definitely assist to regional planners, administrator and policy makers for combating such hydro-environmental hazard as well as to improve the livelihood of the local people. The uniqueness of the study is to identify the pattern of declining trend of groundwater table along with regional depression pockets through most reputed methods. The main objectives of the study are (i) to analyse the seasonal (post-monsoon and pre-monsoon) groundwater level variability and fluctuation trend through nonparametric statistical method with future prediction and (ii) to investigate the reasons behind the groundwater table fluctuation in Precambrian hard rock terrain.

\section{Study area}

Purulia district is located in the western part of West Bengal and the topographical characteristics of Purulia district are similar to Chota Nagpur plateau region and it is an extended part of Chota Nagpur gneissic complex. Latitudinal and longitudinal extension of Purulia district is $22^{\circ} 42^{\prime} 19^{\prime \prime} \mathrm{N}$ to $23^{\circ} 42^{\prime} \mathrm{N}$ and $85^{\circ} 49^{\prime} 19^{\prime \prime} \mathrm{E}$ to $86^{\circ} 54^{\prime} 25^{\prime \prime} \mathrm{E}$ with 6259 sq $\mathrm{km}$ area (Fig. 1). Climatologically, the study area is under subtropical and semi-arid region along with dry winter and hot wet summer (Dolui et al. 2014). The whole district is drained by different principal rivers such as Damodar, Subarnarekha,
Kumari, Kangsabati and their tributaries (Bera et al. 2019; Nayak et al. 2020). Regionally, this is a part of eastern Indian peninsular shield and Chota Nagpur Gneissic complex (CGC). This region consists with granitic rock and metasediments of Precambrian age which is considered as a basement rock or the fundamental rock of this area and the whole region is situated in the northern part of Singhbhum craton (Dunn and Dey 1942; Chakraborty et al. 2021).

\section{Lithological and aquifer characteristics of Chota Nagpur Gneissic Complex (under Singhbhum Protocontinent)}

A triangular shaped Singhbhum Protocontinent is bounded by Eastern Ghats Granulite Belt in the south, Mahanadi Lineament (Rift Basin) in the southwest, Damodar Valley Rift Basin in the north and the youngest sediment-filled Bengal Basin in the east (Fig. 2b). Singhbhum Protocontinent consists of three adjacent states like Odisha, Chhattisgarh, Jharkhand and West Bengal. The Protocontinent encompasses three main lithotectonic blocks: the Chota Nagpur Gneissic Complex in the north, the North Singhbhum Fold Belt in the middle and the Singhbhum Granite Complex in the south.

The Chota Nagpur Gneissic Complex is also portrayed as the Chota Nagpur Granite-Gneiss Complex which is situated between the North Singhbhum Fold Belt in the south and the Damodar Valley Rift Basin in the north (Roy 2012). The Chota Nagpur Gneissic Complex contains largely gneisses 


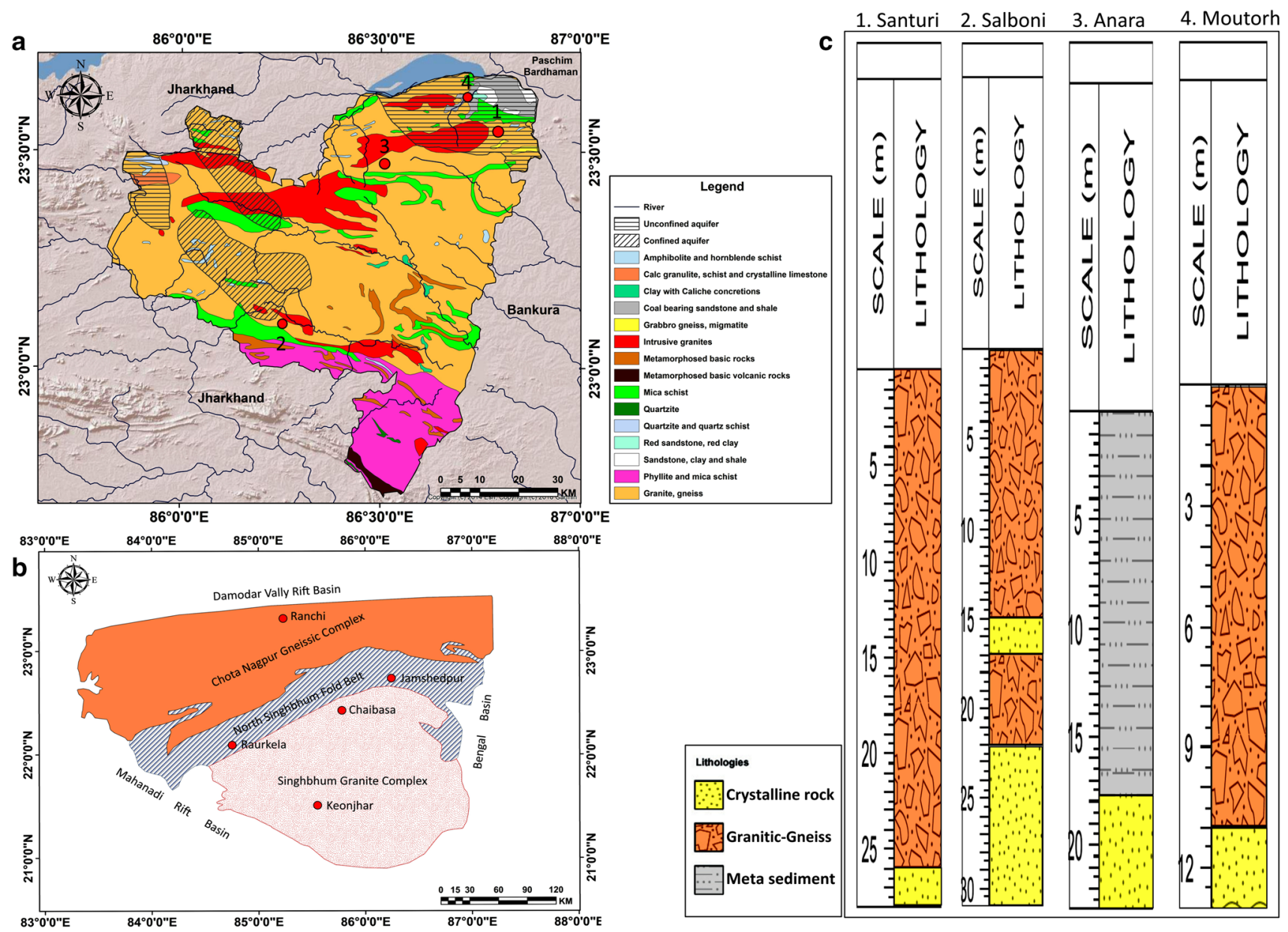

Fig. 2 a Hydro-geological map of Purulia district. b Geological map shows principal lithotectonic units of the Singhbhum Protocontinent. c Lithologs showing the lithological condition of different parts of the Purulia district

and granitoids of various petrological compositions. The gneiss shows distinctive banded character that appears quite like to those comprising the ancient basement rocks in diverse parts of the Indian Shield. There are few gneissic rocks which are also characterised by mafic in character and these are illustrated as diorite gneiss. The amphibolite is also termed as hornblende gneiss (Pascoe 1973) and the different shapes and sizes hornblende gneiss is occasionally found as enclaves within the gneiss-granite complex. Few gneissic rocks have consistently layered and planner shaped fabric of secondary origin that is also depicted as mylonite gneiss (Roy et al. 2016). Numerous bodies of granites are occurred in the form of isolated plutons in the Chota Nagpur Gneissic Complex. Majority of the granite plutons are found in the Ranchi-Purulia Belt. Broadly, the granites are coarse-grained and porphyritic type. These are continuously weathered and turned into rounded, domelike bosses and tors. Primarily, the grey and pink coloured granites have been identified in the Chota Nagpur Gneissic Complex and the grey granites have been originated from the melting of tonalite-trondhjemite-granodiorite gneisses (Roy 2012). The 'pink' granite is the youngest intrusive bodies within the gneissic complex (Saxena et al. 1992; Mahadevan 1992). Mainly metasedimentary and metavolcanic rocks of supracrustal bodies occupy as enclaves within the gneissic rocks. These supracrustal rocks include mica schist, marble, banded iron formation and quartzite along with patches of mafic and ultramafic rocks. The high grade granulite facies have been found mainly along two belts e.g. (i) in the eastern part of Purulia district of West Bengal and (ii) in the Ranchi-Palamau area in Jharkhand (Mahadevan 2002). The most significant presence of lenticular or elliptical bodies of anorthosite has been identified in the Chota Nagpur Gneissic Complex and locally it is coupled with thin lenses of syenite (Mahadevan 2002; Bera et al. 2019). The biggest body of anorthosite has been occupied at the eastern margin of the Singhbhum Protocontinent. Around 40-km-long 'tadpoleshaped' intrusive body is termed as the Bengal Anorthosite (Ghosh et al. 2008) which is encircled by politic granulites and felsic gneisses (Bhattacharya and Mukherjee 1987). 
It has been observed that in northern Singhbhum craton area most of the aquifer systems are semi confined aquifer. Unconfined aquifer system has been observed in the western part and north eastern part of Purulia district and the major rock systems of this unconfined aquifer zone are amphibolites, hornblende, mica schist, intrusive granite, crystalline limestone etc. (Fig. 2a). The formation of these aquifers is confined between Palaeozoic to Jurassic age and the groundwater potentiality and permeability is always high in this kind of water bearing layers (Bera et al. 2021a). Groundwater potentiality and permeability is very low in this water containing layers. Amphibolite, calcareous granulite, mica schist are the significant rock system in this water holding layers. In granitic gneiss terrain, the movement of groundwater is totally controlled by lithological characteristics (Fig. 2c), topography, joints, fractures, depth of weathered zone etc. (Bhattacharya 1989; Acharya and Prasad 2017; Bera and Ghosh 2019).

\section{Materials and method}

\section{Data set}

To analyse the pattern of groundwater assessment of Purulia district, groundwater (monitoring well) data have been collected from CGWB (central groundwater board), Government of India. Data of total 21 consecutive years (1996-2017) have been extracted in a periodic form (premonsoon and post-monsoon). The digital elevation model (DEM) of Purulia district has been downloaded from USGS website (https://earthexplorer.usgs.gov/). The long-term rainfall data have been extracted from MINISTRY OF JAL SHAKTI website, Government of India (https://indiawris. gov.in/wris/). Lithologs data have been obtained from IndiaWRIS website, government of India.

\section{Mapping of variability of groundwater table through interpolation}

Precise mapping of spatial and periodic variability (postmonsoon and pre-monsoon) of groundwater table or groundwater level requires spatial interpolation method. In this research kriging method has been applied for spatial interpolation considering different monitoring borehole water depth data of different years (1996, 2001, 2006, 2011 and 2016) in a periodic time scale (post- and pre-monsoon).

\section{Kriging method}

Kriging is a robust geo-statistical method which is considered as optimum approach for interpolating the unknown locations. The primary benefit of kriging is that it offers the estimation opportunity of the interpolation error of the values of the regionalized variable where there are no initial measurements (Adhikary et al. 2010). Kriging method is a reliable interpolation estimator associated with maximum linear and non-biased estimate with minimum variance (Rasel et al. 2019). The spatial dependence of kriging method has been quantified through Semivariogram and mathematically it described as mean square variability between two neighbouring values (Burgess and Webster 1980). It follows,

$\gamma(h)=\frac{1}{2 N(h)} \sum_{i=1}^{N(h)}\left[z\left(x_{i}+h\right)-z\left(x_{i}\right)\right]^{2}$

where $\gamma(h)$ refers the Semivariogram, $N(h)$ signifies number of observation that is separated by distance (h) and $z\left(x_{i}\right)$ means the random variable.

Here, Nugget is used for error measurement and the range is the distance at which the semivariance starts to level off, whereas the sill is the semivariance at which the levelling takes place.

\section{Mann-Kendall test}

Mann-Kendall trend test is one of the most significant nonparametric tests which are commonly used for statistical significant trend analysis of different time series data (Kendall 1975). As it is a nonparametric test so it does not require the data in a particular distributional form. In case of Mann-Kendall test, two hypotheses have been constructed: null hypotheses $\left(\mathrm{H}_{0}\right)$ and alternative hypotheses $\left(\mathrm{H}_{1}\right)$. Null hypothesis signifies that there is no trend in the dataset, whereas the alternative hypothesis defines that there is a presence of positive or negative trend (Halder et al. 2020). Chatterjee et al. (Chatterjee et al. 2020) have successfully applied Mann-Kendall test for the determination of the fluctuation trend of groundwater table in Murshidabad district of Bengal (India). In this research, Mann-Kendall test has been applied over a long-term groundwater data set (1996-2017) to properly demarcate the positive or the negative trend of the groundwater level in the study area. The entire process has been performed using R-Studio programming package with the help of 26 different observatory tube well data. It follows, 
$S=\sum_{k=1}^{n-1} \sum_{j=k+1}^{n} \operatorname{sign}\left(x_{j}-x_{k}\right)$

where $S$ defines Mann-Kendall statistics, $n$ means sample size and sign indicates signum function.

Where

$$
\begin{aligned}
\operatorname{sign}\left(x_{j}-x_{k}\right) & =1 \quad \text { if } x_{j}-x_{k}>0 \\
& =0 \quad \text { if } x_{j}-x_{k}=0 \\
& =-1 \quad \text { if } x_{j}-x_{k}<0
\end{aligned}
$$

If $n<10$, the value of S directly compared to the theoretical distribution of $S$. If $n>10$, the $S$ variance follows,

$\operatorname{Var}(S)=\frac{n(n-1)(2 n+5) \sum_{i=1}^{m} t_{1}(i)(i-1)(2 i+5)}{18}$

The test statistics $Z_{C}$ follows,

$$
\begin{aligned}
Z_{C} & =\frac{S-1}{\sqrt{\operatorname{Var}(S)}} \quad \text { if } S>0 \\
& =0 \quad \text { if } S=0 \\
& =\frac{S+1}{\sqrt{\operatorname{Var}(S)}} \quad \text { if } S<0
\end{aligned}
$$

Here $Z_{C}$ follows a standard normal distribution.

\section{Sen's slope estimator}

Sen's slope estimator was proposed by Sen and it has been used to calculate the statistically significant magnitude of the trend (Sen 1968). This statistical method has been widely used by the researchers in case of time series data such as hydro-meteorological data, different climatic data, etc. Sen's slope estimator provides us statistically accurate result than simple linear regression model. In this research, Sen's slope has been performed to analyse the magnitude of the groundwater level data trend. Sen's slope is following the equation.

Table 1 Drought type classification table based on SPI values

\begin{tabular}{ll}
\hline SPI values & Classes \\
\hline Above 2.0 & Extremely wet \\
1.50 to 1.99 & Very wet \\
1.00 to 1.49 & Moderately wet \\
-0.99 to +0.99 & Normal \\
-1.00 to -1.49 & Moderately dry \\
-1.5 to -1.99 & Severe dry \\
Below -2 & Extremely dry \\
\hline
\end{tabular}

$\left(Q_{i}\right)=\frac{x_{j}-x_{k}}{j-k} \quad i=1,2, \ldots N$

where $x_{j}$ and $x_{k}$ represent the values of the data.

Where $\mathrm{N}$ is the number of data pairs where,

$x_{j}>x_{k}=\frac{n(n-1)}{2}$

\section{Analysis of standardized precipitation index (SPI)}

Standardized precipitation index is a widely used statistical index which can statistically measure the meteorological drought on the basis of long-term monthly precipitation data. The SPI is closely related to soil moisture and precipitation. Presently, standardized precipitation index becomes an efficient and useful index to calculate the onset, duration and magnitude of meteorological drought events by SPI values (Table 1) (McClaran and Wei 2014). It is a statistical indicator that compares the total or the accumulated rainfall within a restricted timeframe or a specific month to long-term cumulated rainfall (Nam et al. 2012). SPI can be calculated by the different time scale such as 1-, 3-, 12- and 48-month time scale. In this research SPI has been calculated to demarcate the anomaly or variability of dry climatic condition as well as the drought condition. SPI follows,

$\mathrm{SPI}=\frac{X-X m}{\sigma}$

where $X$ means Precipitation of the station, $X m$ indicates mean precipitation and $\sigma$ demarcates standardized deviation.

Determination of SPI is based on long-term precipitation data. Gamma distribution function is highly used and it has advantage to fitting the probability data. It can be estimated by the following formula (McKee et al. 1993).

$g(x)=\frac{1}{\beta^{\alpha} \Gamma(\alpha)} x^{a-1} e^{-x / \beta}$

where $a>0, b>0$ and $x>0$ signifies shape parameters, scale parameters and precipitation accumulation. The gamma function $\Gamma(\alpha)$ portrays as,

$\Gamma(a)=\int_{0}^{\infty} y^{\alpha-1} e^{-y} d y$

The SPI can be calculated by transforming the cumulative probability with null average to a standardized distribution (McKee et al. 1993). 
$\mathrm{SPI}=\left\{\frac{-\left(t-\frac{C_{0+} C_{1} t+C_{2} t^{2}}{1+d_{1} t+d_{2} t^{2}+d_{2} t^{2}}\right)}{+\left(t-\frac{C_{0+} C_{1} t+C_{2} t^{2}}{1+d_{1} t+d_{2} t^{2}+d_{2} t^{2}}\right)}\right\}$

where $C_{0}=2.5155, C_{1}=0.8028, C_{2}=0.0103, d_{0}=1.4327, d_{1}$ $=0.1892, d_{2}=0.0013$

\section{Analysis of LULC through maximum likelihood classifier}

The changing pattern of LULC has been analysed because there is a close relationship between LULC and groundwater depletion of any region. In the recent years, largescale anthropogenic activities may deplete the groundwater
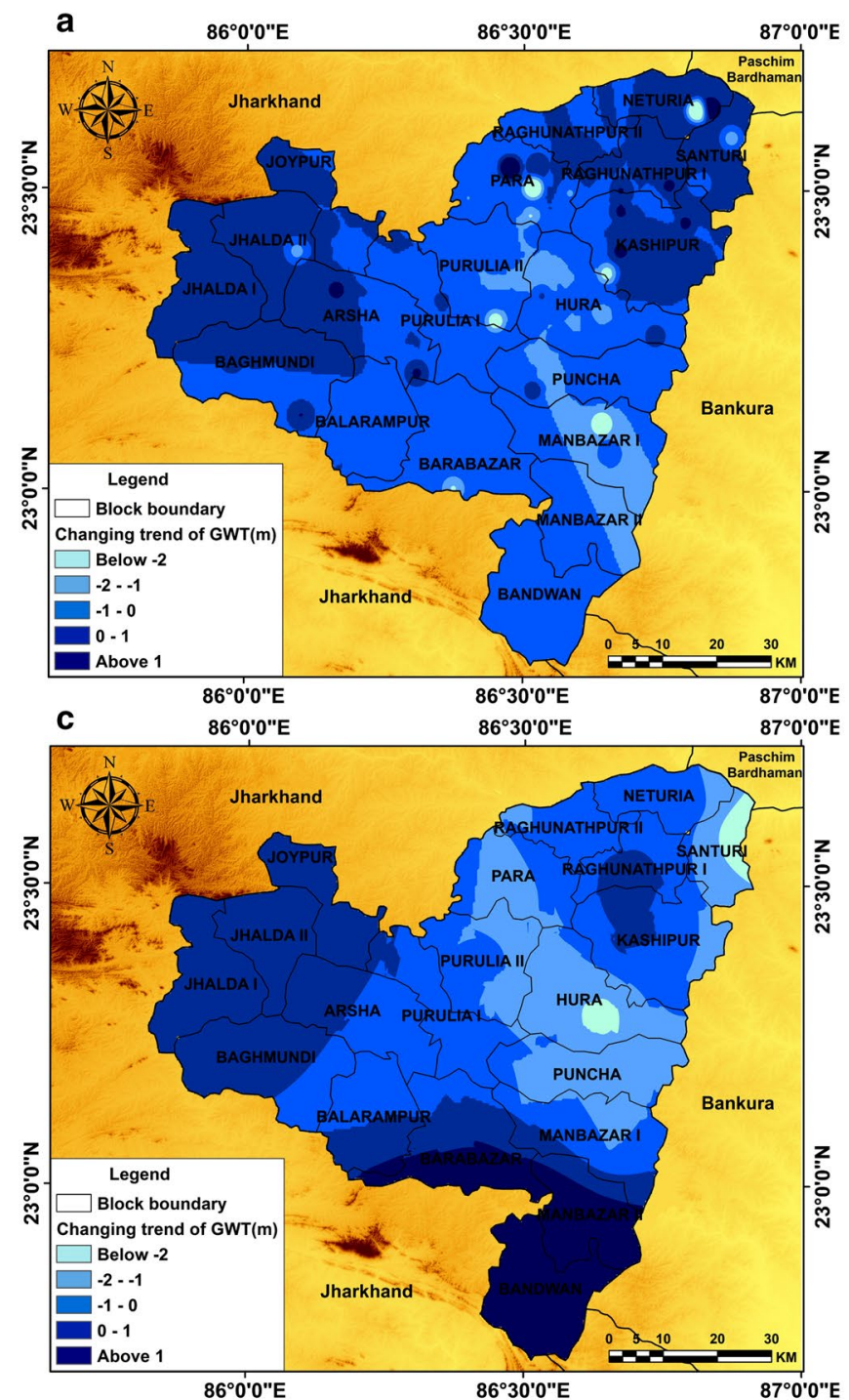

equilibrium trend of a particular region. So, total three LULC maps have been prepared considering 10-year interval (2000, 2010 \& 2020) period. Subsequently, Landsat images have been considered and Erdas Imagine software is used to find out the actual changing scenario of LULC in last two decades and correlates it with groundwater fluctuations trend.

\section{Standard groundwater level index (SGWI) and future prediction}

Determination of Standard groundwater level index (SGWI) is similar to standardized precipitation index (SPI) that is a quantitative approach to determine the groundwater level depletion for long-term average scenario. It can easily
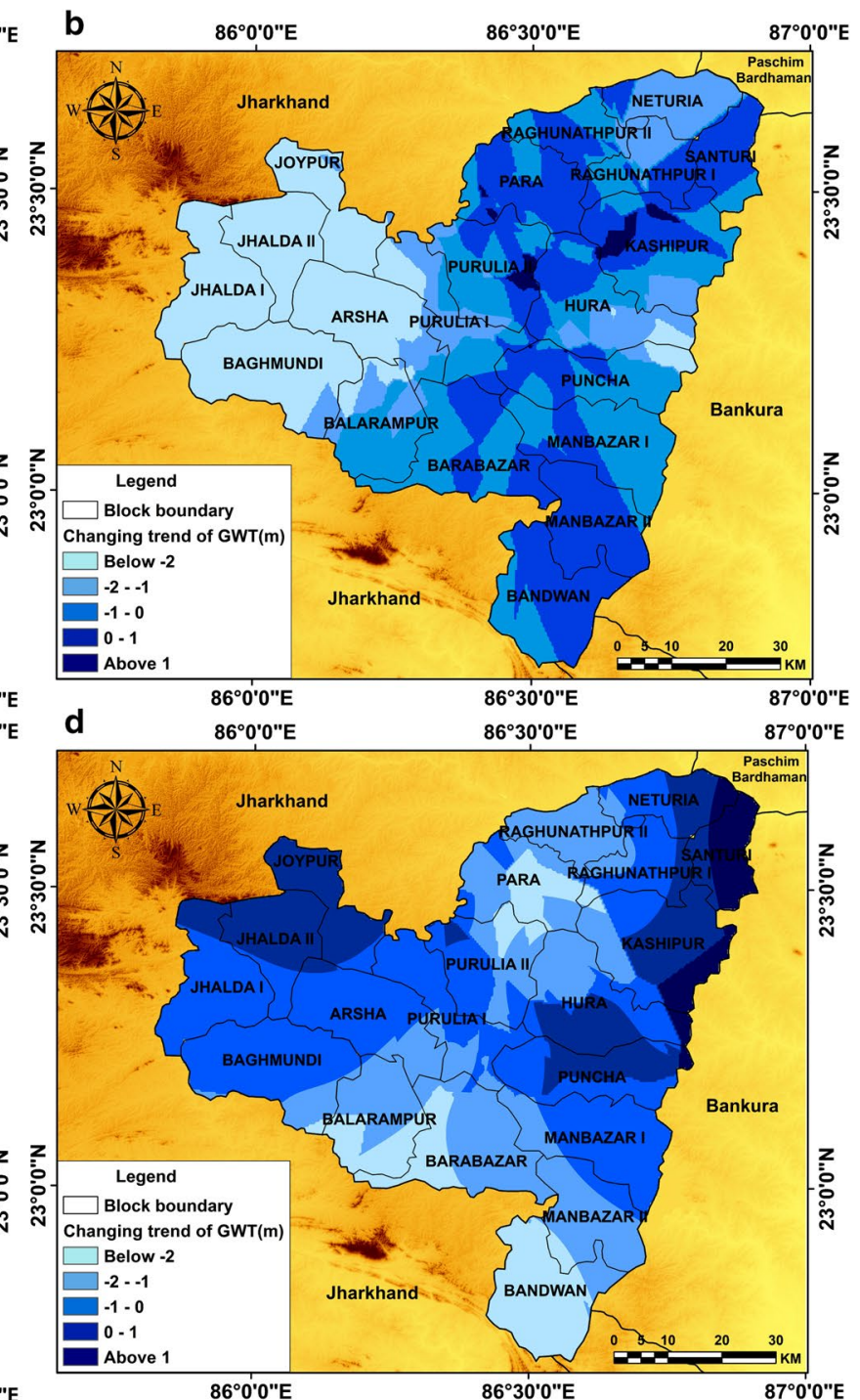

Fig. 3 Changes of groundwater height scenario at Purulia district of different years in pre monsoon season, a 1996-2001, b 2001-2006, c 20062011, d 2011-2016 

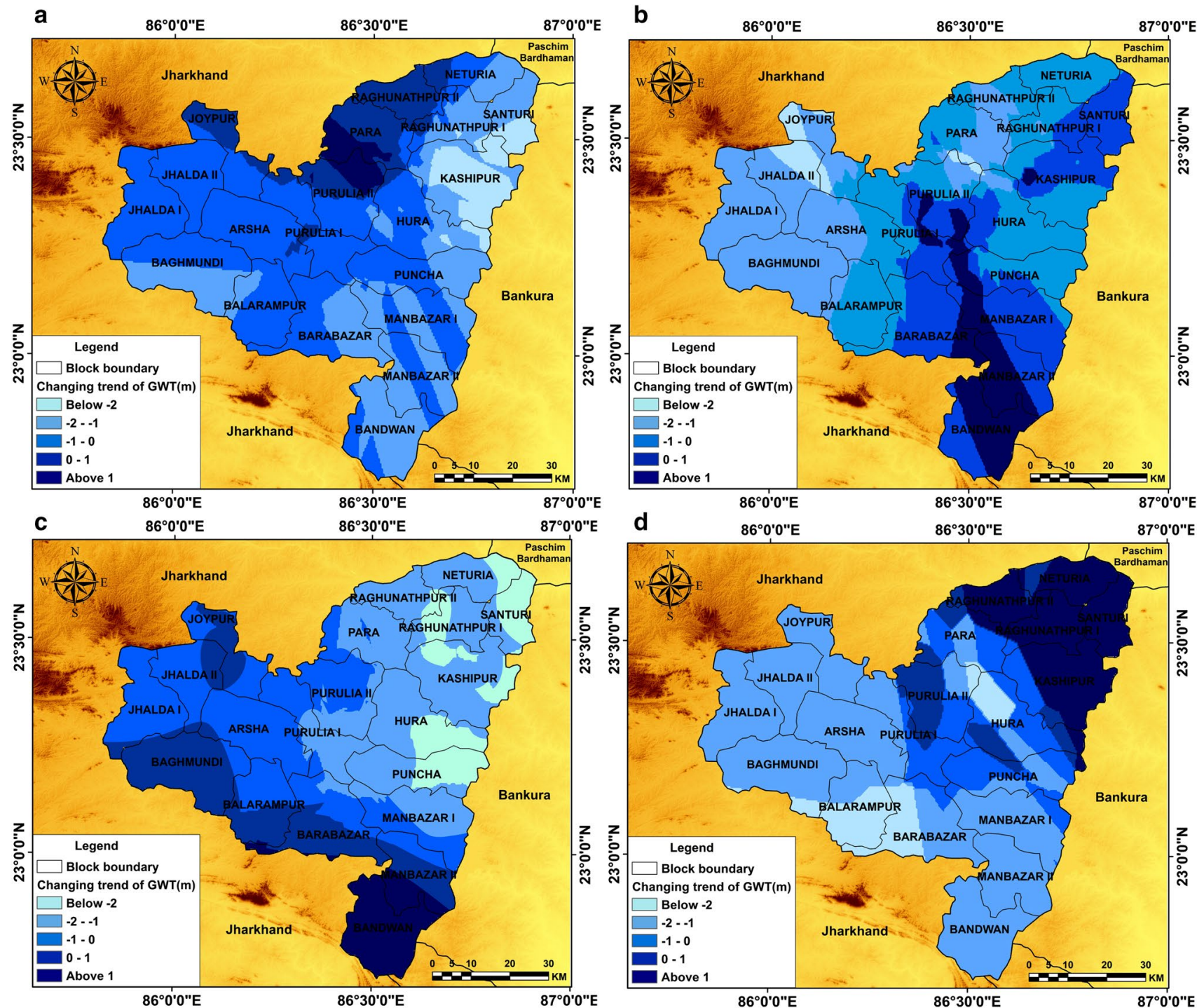

Fig. 4 Changes of groundwater height scenario at Purulia district of different years in post monsoon season, a 1996-2001, b 2001-2006, c 2006-2011, d 2011-2016

determine the groundwater deficit and groundwater drought condition for a particular time period. Standardised groundwater level index can easily evaluate the groundwater deficiency of a region on the basis of previous measured groundwater level data in different temporal scale. Based on SGWI, we can directly identify the drought affected years and based on this index the level of water scarcity and its variation can be observed (Pathak and Dodamani 2019).

Here, groundwater drought condition has been calculated over different sample sites over Purulia district for pre- and post-monsoon time period since 1996 to 2017. It is calculated applying the given equation.

$\mathrm{SGWI}=\frac{X-M}{\sigma}$
Here, SGWI indicates Standard groundwater level index, $X$ demarcates the height of groundwater table of that particular year. $M$ and $\sigma$ indicate mean and standard deviation, respectively, in the restricted time frame.

A future prediction has been done over the groundwater level data to determine the futuristic condition and probable groundwater scare or depressed zones. For forecasting, two widely used exponential smoothing methods are Holt-Winter soothing and simple exponential (Hyndman et al. 2008). The statistical based Holt-Winter exponential smoothing method has been used to forecast the future groundwater level scenario. Holt-Winters' Exponential Smoothing method has been employed for spatiotemporal trend analysis of groundwater table in Malayer plain due to over exploitation and Kabudarahang aquifer, Iran (Sakizadeh 
Table 2 Result of MannKendall trend test on premonsoon groundwater table data

\begin{tabular}{|c|c|c|c|c|c|c|}
\hline Borehole location & $Z$ & $P$ value & $S$ & Vars & Kendall tau & Sen's slope \\
\hline Kantadihi & -3.628 & 0.00028 & -89 & 588.33 & -0.6568 & -0.205 \\
\hline Barabazar & -0.7696 & 0.04415 & -23 & 817 & -0.1345 & -0.065 \\
\hline Banduan & 0.818 & 0.04133 & 30 & 1256.66 & 0.13015 & 0.036 \\
\hline Baghmundi & -1.2252 & 0.022 & -36 & 816 & -0.2111 & -0.045 \\
\hline Mathabura & -2.8514 & 0.0043 & -102 & 1254.66 & -0.4444 & -0.130 \\
\hline Hura & -2.3686 & 0.0178 & -85 & 1257.66 & -0.3679 & -0.122 \\
\hline Bispuria & -2.0593 & 0.0394 & -74 & 1256.66 & -0.321 & -0.069 \\
\hline Joypur-I & -0.28835 & 0.0773 & -8 & 589.33 & -0.0588 & -0.044 \\
\hline Kotshila-I & -1.4846 & 0.1376 & -31 & 408.33 & -0.2952 & -0.105 \\
\hline Naduara & 0.0757 & 0.0939 & 3 & 697 & 0.0196 & 0.009 \\
\hline Palashkhola & -0.1557 & 0.04763 & -3 & 165 & -0.05454 & -0.006 \\
\hline Manbazar & -1.277 & 0.0201 & -32 & 589.33 & -0.2352 & -0.074 \\
\hline Ankro62 & -0.3757 & 0.0707 & -3 & 28.333 & -0.2 & -0.125 \\
\hline Gobag & 1.1566 & 0.0247 & 42 & 1256.66 & 0.1822 & 0.095 \\
\hline Neturia & -0.4379 & 0.06614 & -9 & 333.66 & -0.0989 & -0.115 \\
\hline Anara & -1.1494 & 0.025 & -39 & 1093 & -0.187 & -0.023 \\
\hline Dabra & -1.8493 & 0.05 & -58 & 950 & -0.3052 & -0.099 \\
\hline Kenda-I & -0.5366 & 0.05 & -7 & 125 & -0.1555 & -0.108 \\
\hline Bagda20 & -0.4671 & 0.046 & -7 & 165 & -0.1272 & -0.090 \\
\hline Tamna & -3.1549 & 0.0016 & -98 & 945.33 & -0.5213 & -0.093 \\
\hline Chakaltore & -1.4675 & 0.0142 & -53 & 1255.66 & -0.2304 & -0.055 \\
\hline Podalaroad & -1.9024 & 0.0471 & -64 & 1096.66 & -0.3047 & -0.068 \\
\hline Kustar-I & -1.6314 & 0.102 & -55 & 1095.66 & -0.2625 & -0.051 \\
\hline Chinpina & 1.6092 & 0.1076 & 40 & 587.33 & 0.2963 & 0.085 \\
\hline Suisa-2 & 0.5355 & 0.0392 & 14 & 589.33 & 0.1029 & 0.115 \\
\hline Balitora & 0.818 & 0.0413 & 30 & 1256.66 & 0.1301 & 0.036 \\
\hline
\end{tabular}

et al. 2019; Khorasani et al. 2016). This trend method also used for forecasting of water level of the Mtera dam, Tanzania (Mgandu et al. 2020). This method can easily provide the future forecasting value in an effective way (Razali et al. 2018). Future depression zone map of 2040 (Fig. 10) has been prepared using Surfer software. This method follows,

$$
\begin{aligned}
& L_{t}=\alpha\left(Y_{t}-S_{t-m}\right)+(1-\alpha)\left(L_{t-1}+b_{t-1}\right) \\
& b_{t}=\beta\left(L_{t}-L_{t-1}\right)+(1-\beta) b_{t-1} \\
& S_{t}=\gamma\left(Y_{t}-L_{t}\right)+(1-\gamma) S_{t-m}
\end{aligned}
$$

where, $L_{t}, b_{t}, S_{t}$ signify level, trend and season, respectively.

\section{Results}

\section{Spatial and periodic variation and trend of groundwater table}

Declining trend of groundwater table is related with the unscientific extraction of this natural resource from the concerned aquifer system (Russo and Lall 2017). To determine the changing pattern, distribution and variation of groundwater table in pre- and post-monsoon, the borehole data were analysed for the time frame (1996-2017). It is observed that in the selected years (1996, 2001, 2006, 2011 and 2016) along with various seasons, groundwater table height was above $250 \mathrm{~m}$ from M.S.L (approximately $25 \%$ monitoring wells) in western areas, particularly the blocks of Arsha, Jhalda, Balarampur, Baghmundi etc. whereas the groundwater table was below $250 \mathrm{~m}$ (approximately $75 \%$ monitoring wells) in the north-east and eastern parts of the region particularly the blocks of Santui, Puncha, Manbazar, Raghunathpur I \& II etc. The changing pattern of groundwater level has been analysed for different periods (1996-2001, 2001-2006, 2006-2011 and 2011-2016) in both the seasons (Figs. 3a-d, 4a-d). It has been detected that most of 
Table 3 Result of MannKendall trend test on postmonsoon groundwater table data

\begin{tabular}{|c|c|c|c|c|c|c|}
\hline Borehole location & $Z$ & $P$ value & $S$ & Var & Kendall tau & Sen's slope \\
\hline Kantadihi & -1.439 & 0.015 & -39.000 & 697.000 & -0.255 & -0.060 \\
\hline Barabazar & -0.332 & 0.074 & -12.000 & 1094.667 & -0.057 & -0.005 \\
\hline Banduan & 1.540 & 0.012 & 52.000 & 1096.666 & 0.248 & 0.229 \\
\hline Baghmundi & -0.385 & 0.070 & -12.000 & 816.000 & -0.070 & -0.010 \\
\hline Mathabura & -1.072 & 0.028 & -39.000 & 1257.666 & -0.169 & -0.062 \\
\hline Hura & -1.410 & 0.015 & -51.000 & 1257.660 & -0.221 & -0.053 \\
\hline Bispuria & -1.242 & 0.021 & -45.000 & 1255.660 & -0.565 & -0.030 \\
\hline Joypur-I & 0.303 & 0.076 & 9.000 & 697.000 & 0.059 & 0.020 \\
\hline Jhargo 23 & -0.894 & 0.037 & -11.000 & 125.000 & -0.244 & -0.051 \\
\hline Kotshila-I & -1.789 & 0.054 & -21.000 & 125.000 & -0.467 & -0.173 \\
\hline Naduara & -1.212 & 0.023 & -33.000 & 697.000 & -0.216 & -0.156 \\
\hline Palashkhola & -2.409 & 0.016 & -45.000 & 333.666 & -0.495 & -0.192 \\
\hline Manbazar & -0.865 & 0.039 & -22.000 & 589.330 & -0.162 & -0.079 \\
\hline Ankro62 & -0.751 & 0.045 & -5.000 & 28.333 & -0.333 & -0.110 \\
\hline Gobag & -0.060 & 0.952 & -3.000 & 1095.660 & -0.014 & -0.008 \\
\hline Neturia & -1.642 & 0.010 & -31.000 & 333.660 & -0.341 & -0.060 \\
\hline Anara & -0.846 & 0.040 & -29.000 & 1095.666 & -0.138 & -0.022 \\
\hline Dabra & -1.006 & 0.031 & -32.000 & 950.000 & -0.168 & -0.070 \\
\hline Kenda-I & -1.789 & 0.074 & -21.000 & 125.000 & -0.467 & -0.173 \\
\hline Bagda20 & 0.343 & 0.043 & 6.000 & 212.666 & 0.091 & 0.023 \\
\hline Tamna & -2.757 & 0.006 & -86.000 & 950.000 & -0.453 & -0.096 \\
\hline Chakaltore & -1.006 & 0.031 & -32.000 & 950.000 & -0.168 & -0.015 \\
\hline Podalaroad & -1.963 & 0.050 & -66.000 & 1096.666 & -0.314 & -0.040 \\
\hline Kustar-I & -1.611 & 0.011 & -47.000 & 815.000 & -0.276 & -0.086 \\
\hline Chinpina & -0.842 & 0.040 & -18.000 & 407.333 & -0.172 & -0.031 \\
\hline Suisa-2 & 0.371 & 0.711 & 10.000 & 589.330 & 0.074 & 0.095 \\
\hline Balitora & -2.099 & 0.036 & -61.000 & 817.000 & -0.357 & -0.074 \\
\hline
\end{tabular}

the period (1996-2001, 2001-2006 and 2006-2011), the groundwater table height has dropped within 0 to $-3 \mathrm{mts}$ in both the periods (approximately 45-65\% monitoring wells), particularly the eastern and middle parts of the region. But within the period 2011-2016, a positive trend of groundwater table has been observed. In this period approximately $45 \%$ stations have faced a rising trend (0 to $3 \mathrm{mts}$ ), mostly eastern and western parts of the study area.

The nonparametric Mann-Kendall test along with Sen's slope estimator can easily predict the significant positive or negative trend with $5 \%$ level of significance in both seasons (pre- and post-monsoon). Around 77\% and 78\% monitoring tube wells have faced a negative trend of groundwater table in pre- and post-monsoon, respectively. In pre-monsoon period a drastic negative trend has been observed in the areas of Kantadihi (-0.205), Kotshila I (-0.105), Ankro62 $(-0.125)$, Neturia $(-0.115)$, Kenda I $(-0.108)$ meter/year (Table 2). Simultaneously, in post-monsoon season, drastic negative trend has been found in the areas of Kenda I (-0.173), Ankro62 (-0.110), Palashkhola (-0.192), Kotshila I (-0.173), Naduara (-0.156) meter/year (Table 3). Figure 9 shows that in pre-monsoon season, the north-eastern blocks of Purulia district particularly Kashipur, Neturia, Raghunathpur I, Raghunathpur II, Para, Santuri face a positive trend of groundwater table whereas in post-monsoon season, only some parts of Bandwan and Raghunathpur I blocks show a slight positive trend of groundwater. Descriptive statistics and error statistics also been given in Table 4.

\section{Analysis the increasing pattern of population and LULC trend}

Manbazar I has faced highest decadal growth rate of population (20.74\%) within the time period 2001-2011, followed by Purulia I, Baghmundi, and Arsha with a rate of $20.64 \%$, $20.57 \%$ and $19.81 \%$, respectively, whereas the lowest decadal growth rate has been observed at Kashipur $(6.97 \%)$ followed by Neturia, Hura and Santuri with a rate of 11.89 , $12.66,12.83 \%$, respectively. So it can be easily concluded that population growth of all the blocks has been tremendously increased in last few years. The LULC maps revealed that the areas of settlement and agricultural land have been tremendously increased in last two decades. Total areas of 
settlement were around 289.57 sq.km, 360.79 sq.km and 409.98 sq.km in 2000, 2010 and 2020, respectively, whereas the areas of agricultural land were 2929.03 sq.km, 3058.21 sq.km and 3378.27 sq.km in 2000, 2010 and 2020, respectively (Figs. 5 1a-1c).

\section{Influence of climatic variable and SPI}

Primarily, the groundwater recharge depends on precipitation rate, intensity and landscape characteristics. Height of groundwater table is highly correlated with the intensity and duration of rainfall. In this research, the rainfall variability has been analysed through standardized precipitation index (SPI) and it is found that rainfall has a slide decreasing trend (Fig. 6) which clearly illustrates the variability or fluctuation of groundwater table under unconfined aquifers. Here, SPI has been analysed by the monthly precipitation data for the period between 1996 and 2020 (Fig. 7) in two different time scale (3 month and 9 month).Total 104 mild droughts, 26 moderate droughts, 6 severe drought and 10 extreme drought months have been identified by the 3-month time scale. Simultaneously, 95 mild drought, 30 moderate drought, 7 severe drought and 8 extreme drought months have been identified through 9-month time scale of SPI within the period 1996-2020 (Table 5) and the result clearly shows the dominancy and high occurring rate of drought. The drought heat map clearly shows the variability, pattern and duration of the drought events in the study area within the time frame (1996-2020) (Fig. 8).

\section{Analysis of the groundwater drought and future water scarcity}

In this research groundwater drought has been calculated using standard groundwater level index from 1996 to 2017. The frequency of groundwater drought has been determined through the data of different wells in Purulia district. It has been observed that total $48 \%$ and $50 \%$ monitoring wells are faced severe groundwater drought problem (less than 2 years recurrence interval) in pre- and post-monsoon, respectively. Jhargo-23 (1.71), Kotshila-I (1.67), Palashkhola (1.38), Podalaroad (1.75), Kusta-I (1.75) and Suisa-2 (1.89) are the remarkable high frequency groundwater drought stations in pre-monsoon period. Whereas Baghmundi (1.9), Barabazar (1.62), Bispuria (1.69), Chinpina (1.88), Gobag (1.75), Joupur-1 (1.64), Kusta-I (1.9), mathabura (1.83) and Tamna (1.82) are the remarkable high frequency groundwater drought stations in post-monsoon period within 1996-2017. Exponential smoothing has been fitted over the groundwater level data for future prediction (2040) to illustrate the future groundwater depression zone as well as high water scarcity 

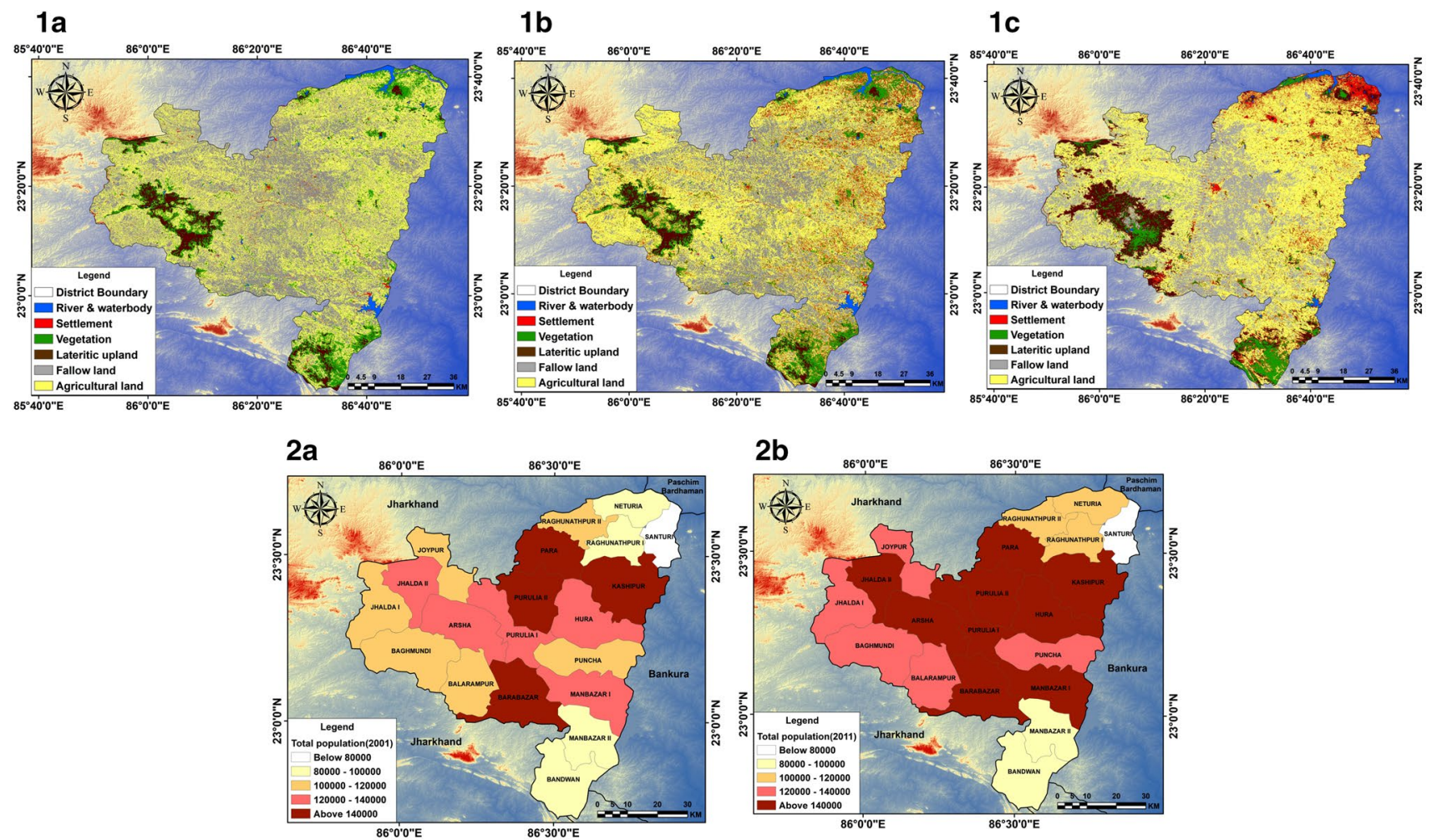

Fig. 5 LULC maps of different years, 1a 2000, 1b 2010 and 1c 2020. Choropleth maps showing the population density of Purulia district of different years, 2a $2001 \mathbf{2 b} 2011$

Fig. 6 Bar graph showing the month wise distributional pattern of rainfall at Purulia district in a time frame of 1996-2020. Here the dotted red line indicates the general trend of rainfall in the restricted time period (1996-2020)

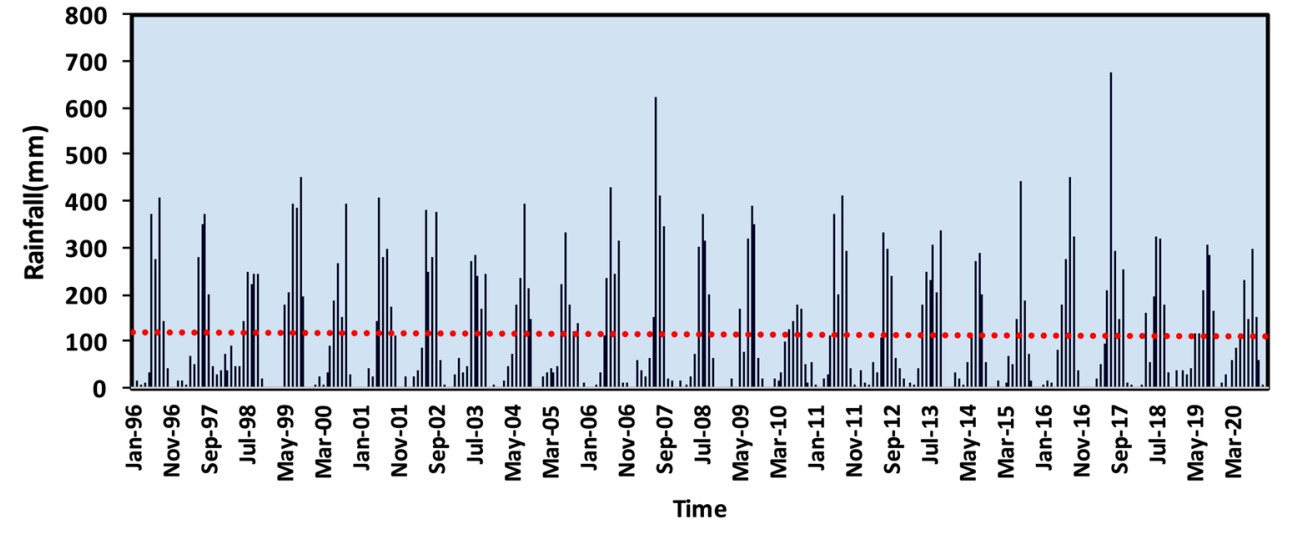

Manbazar (7.6), Naduara (11.6) and Palashkhola (10.1) etc. in 2040 .

\section{Discussion}

The study area comes under sub-tropical and semi-arid region which receives monsoonal rainfall. In summer season, average temperature exceeds above $40{ }^{\circ} \mathrm{C}$. Nowadays, groundwater loss and crisis has become a global calamity particularly due to climatic variability, pollution explosion 
Fig. 7 Standardized precipitation index (SPI) values in different time scale, a 3 month time scale b 9 month time scale
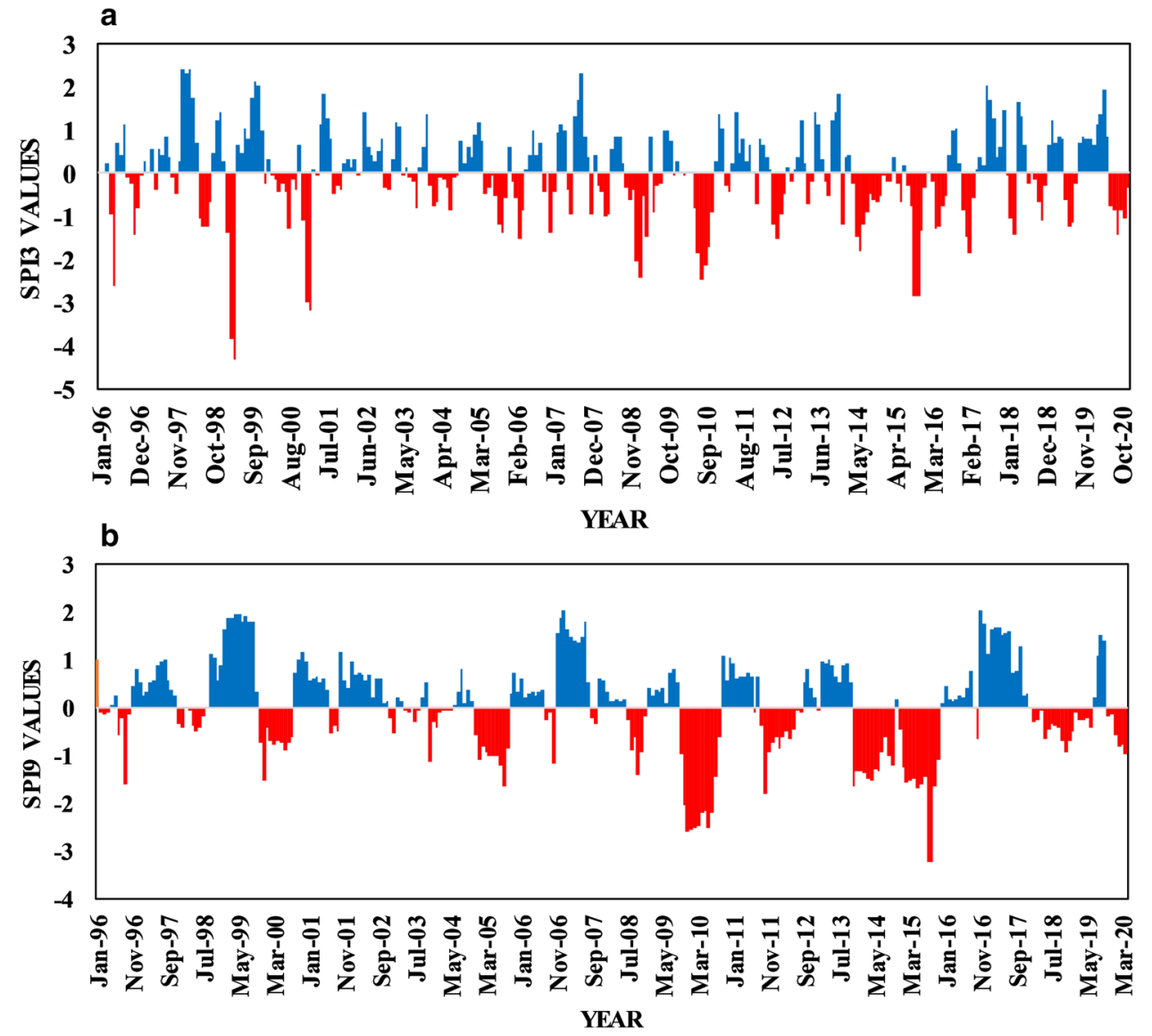

and contamination and excessive stress on groundwater resources. Determination of hydro-geological drought through various groundwater level data can exaggerate the eco-system services (Krogulec 2018). The nonparametric Mann-Kendall test with Sen's slope estimator has been

Table 5 Determination of drought characteristics by SPI index in 3\& 9-month time scale in between the year 1996 and 2020

\begin{tabular}{|c|c|c|c|c|c|}
\hline \multirow[t]{2}{*}{ Period } & \multicolumn{3}{|l|}{ SPI3 } & \multicolumn{2}{|l|}{ SPI9 } \\
\hline & Value & Category & Period & Value & Category \\
\hline Mar 1996 & 0.2373 & Normal & Sep 1996 & -0.1133 & Normal \\
\hline Apr 1996 & -0.9460 & Normal & Oct 1997 & -0.1774 & Normal \\
\hline May 1996 & -2.6049 & $\begin{array}{l}\text { Extremely } \\
\text { Dry }\end{array}$ & Nov 1997 & -0.1604 & Normal \\
\hline Jun 1996 & 0.7165 & Normal & Dec 1997 & -0.1613 & Normal \\
\hline . & . & . & . & . & . \\
\hline . & . & . & . & . & . \\
\hline . & . & . & . & . & . \\
\hline Sep 2020 & -1.4268 & $\begin{array}{l}\text { Moderately } \\
\text { Dry }\end{array}$ & Sep 2020 & -0.286 & Normal \\
\hline Oct 2020 & -0.8335 & Normal & Oct 2020 & -0.7117 & Normal \\
\hline Nov 2020 & -1.0600 & $\begin{array}{l}\text { Moderately } \\
\text { dry }\end{array}$ & Nov 2020 & -0.6994 & Normal \\
\hline Dec 2020 & -0.3575 & Normal & Dec 2020 & -0.7976 & Normal \\
\hline
\end{tabular}

illustrated a declining trend of groundwater in most parts of the region with a high significance level (Fig. 9) due to its tremendous increase of population growth and related anthropogenic stress. A study in Murshidabad district of Bengal depicted that the climatic variability and cropping pattern have a significant impact over groundwater level but the human encroachment over hydraulic regime and continuous pumping through groundwater is responsible for negative trend of water level (Chatterjee et al. 2020; Bera et al. 2021b). The results of land use land cover map of Purulia district clearly indicate a rising trend (15.34\%) of agricultural land within 2000-2020. The increasing trend of drought condition and the extreme drought period are more in the western plateau of West Bengal, particularly the parts of Bankura, Purulia, and some isolated areas in Rarh Bengal where the rapid growth of settlement has been occurred (Pan et al. 2011; Bera et al. 2021b). Some recent studies also highlighted that the severe meteorological and hydrological drought have been identified by regular monitoring of precipitation and underground borehole data (Bloomfield and Marchant 2013). During post-monsoon season, the average regional trend of hydraulic gradient is from north-east and south-east towards the groundwater depression pockets in the middle portion of the region (Fig. 9). 


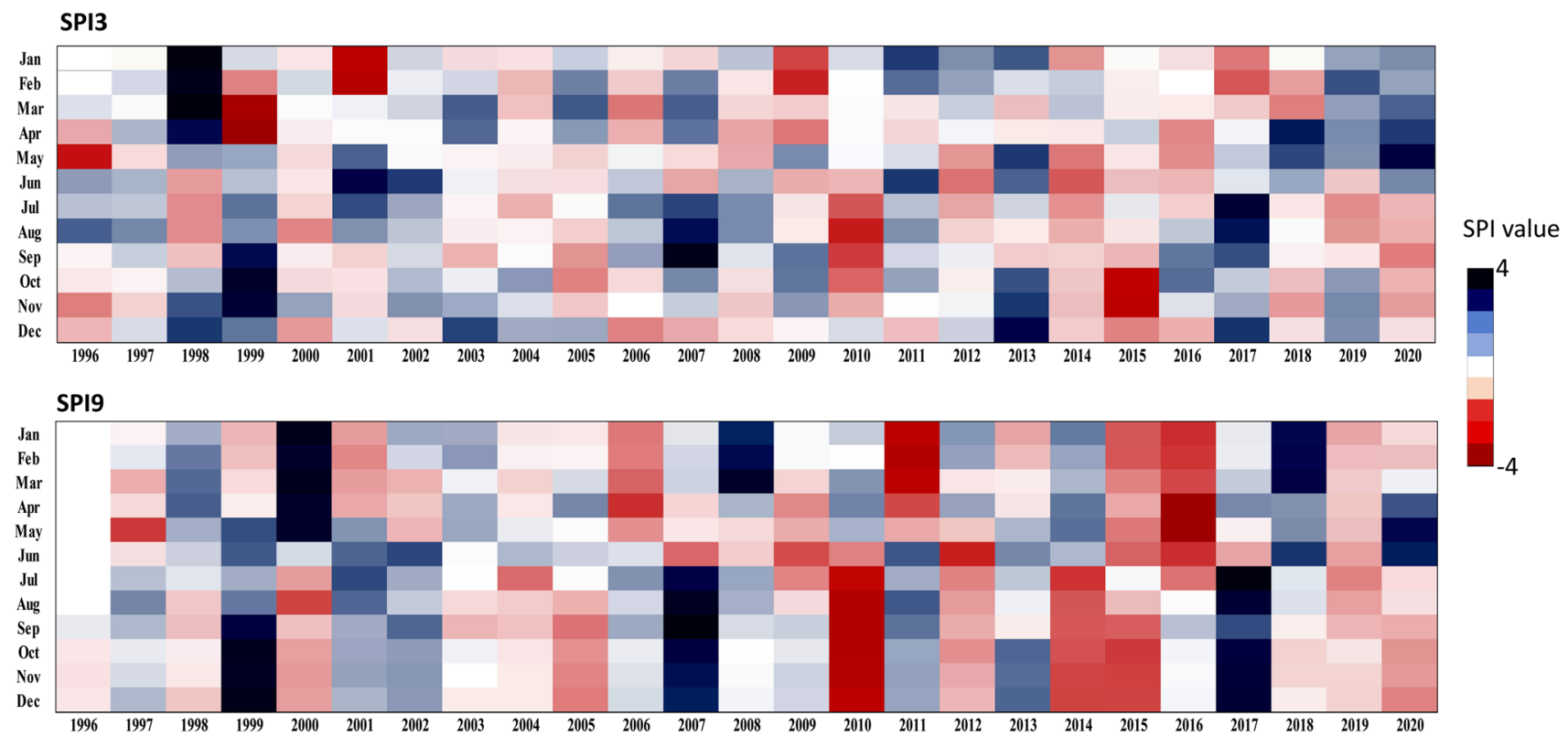

Fig. 8 Drought heat map of SPI3 \& SPI9 showing the drought periods within the restricted time frame

In the last three decades, the drastic change of LULC showed that the surface recharge areas have been reduced along with unscientific withdrawal of groundwater is being increased mainly for high yielding varieties of agriculture in this region (Bera et al. 2021b). Similarly, the Rabi and Kharif crops cultivation have been significantly intensified in the recent years through groundwater irrigation (Bera et al. $2021 b)$. From the future prediction study, it is stated that there is high probability of ground water depression during post-monsoon season in the eastern and western part of Purulia district particularly in Naduara and Hura region (Fig. 10) whereas in pre-monsoon two large groundwater depression pockets will be developed in the middle of eastern and western section of the study area (Fig. 10).

In India, hard rock formation occupies total $65 \%$ geographical area. In hard rock terrain, fluctuation and movement of groundwater mostly dominated by secondary porosity (fracture, structure, fault, lineament etc.) (Saraf and Choudhury 1998). In 2006, the water level in Purulia district was ranged from 4.32-11.68 mbgl and 2.07-5.60 mbgl for pre- and post-monsoon, respectively. In the period 1997-2006, water table in Baghmundi, Barabazar, Arsha, Jhalda, Puncha blocks showed a rising trend of groundwater during pre-monsoon and postmonsoon season (CGWB 2011). Seasonal fluctuation of groundwater table in hard rock aquifer system of Purulia is a common situation and the rising trend of groundwater level is mainly observed in post-monsoon season (Roy 2014). The groundwater occurs within crystalline rocks with weathered residuum in unconfined and semi-confined conditions particularly in the extended part of Chota Nagpur Plateau region (Bera et al. 2021a, d). Subsequently, groundwater storage and movement is largely controlled by joints, fractures and fissures in this Precambrian hard rock terrain (Bera et al. 2021d). In the recent years, it is observed that agricultural and hydrological drought have been experienced due to drastic drop of groundwater table. Pre- and post-monsoonal negative change of groundwater table occurs due to huge withdrawal of groundwater for irrigation and domestic purposes (Bera et al. 2021c). As a result, the groundwater contamination by fluoride ions has been amplified due to speedy interaction between water table and rock-soil (Bera et al. 2021d, e).

\section{Influencing factors of groundwater variability over the study area}

The population growth rate of different blocks of Purulia district has been tremendously changed within last few years. The anthropogenic activities can control the overall groundwater recharge. The land utilization over a region by different human activities such as road, settlements, industries and types of agricultural practice can be an obstacle for the groundwater recharge like infiltration or percolation. Increasing trend of population can convert forestland into bare land 

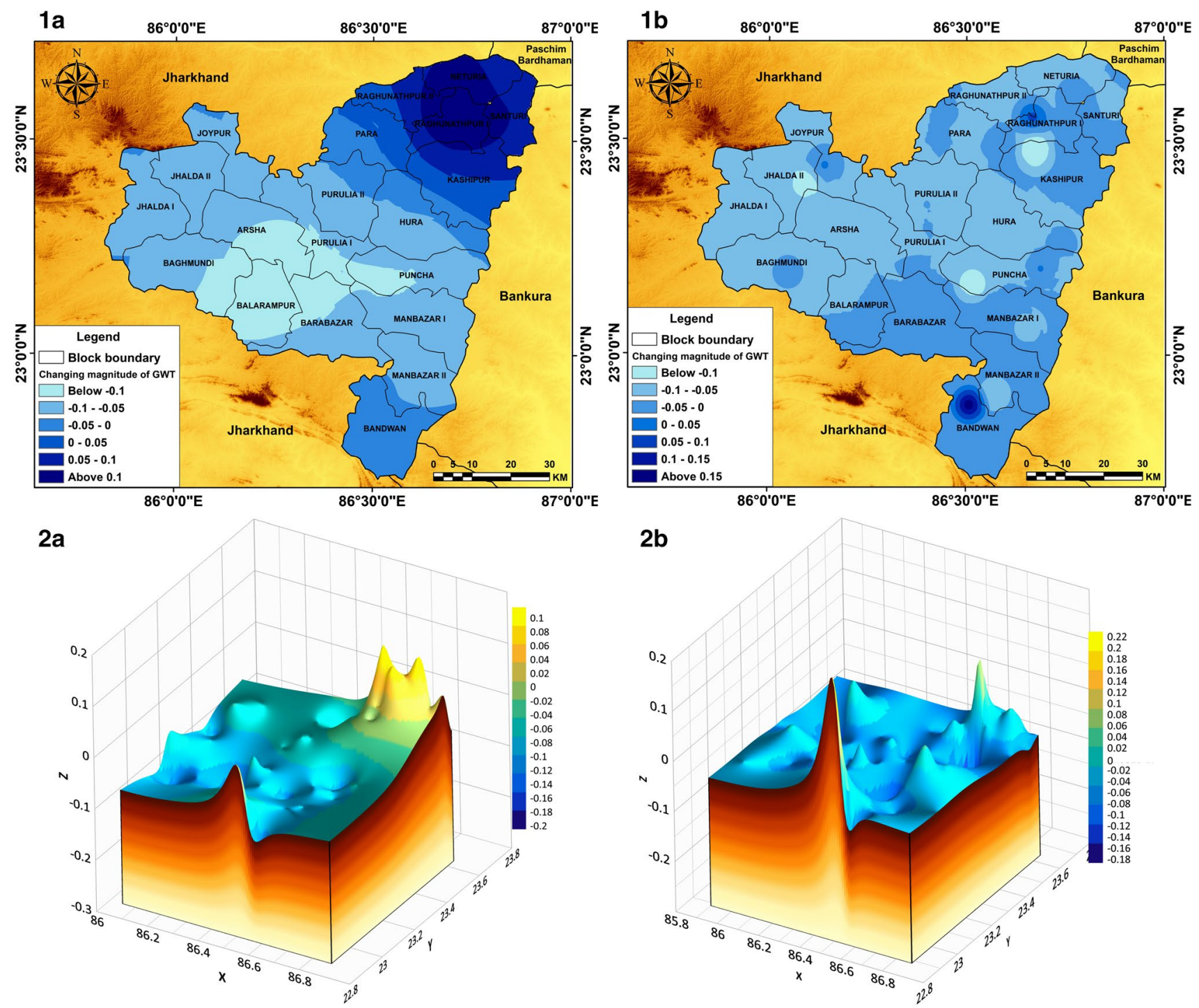

Fig. 9 Interpolation map showing the magnitude of groundwater change with a high statistical significance $(p<0.5)$ between year 1996 and 2017 along with 3D model in different period, a pre monsoon, $\mathbf{b}$ post monsoon

which can increase the surface runoff process and it decreases the recharge capacity into aquifer zones. The declining trend of groundwater table is one of the primary reasons behind groundwater drought. In semi-arid and arid region, climate change is the primary influencing factor on groundwater resources. Generally, groundwater fluctuation depends on precipitation, evaporation and infiltration. But recent changes of these climatic parameters significantly influence the declining trend of groundwater ( $\mathrm{Li}$ et al. 2014). In hard rock aquifer system the groundwater table usually affected by rainfall, topography, slope, aquifer transmissivity, land use land cover, proximity to drainage line (Machiwal and Singh 2015). This scientific study predicted that there is a high probability of groundwater depression in the extended part of Chota Nagpur gneissic complex and the whole region will be faced severe water scarcity. The irregular exploitation of groundwater resource due to anthropogenic activities also increases the discharge of groundwater and it affects the natural flow system of the region. Development of reservoirs in the upstream region can significantly reduce the recharge of groundwater in the lower stream regions ( $\mathrm{Li}$ et al. 2013). The primary factors of groundwater table variability are i. capacity and characteristics of soil, particularly the physical characteristics such as porosity, field capacity, permeability, texture, structure, and infiltration. ii. The climatic variability and changing pattern of climate makes critical condition for natural replenishment 
$1 \mathrm{a}$

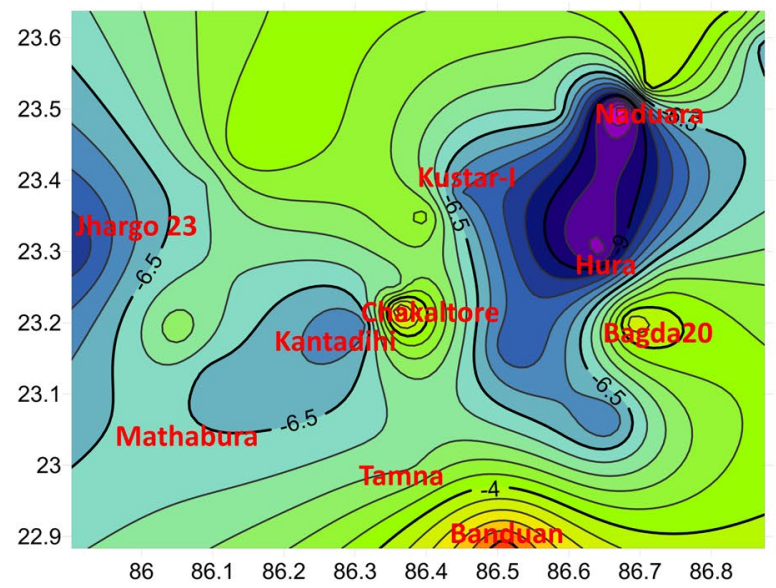

$2 a$

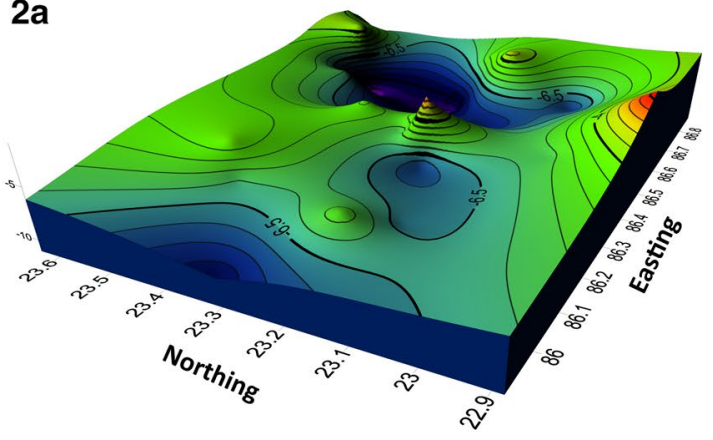

16

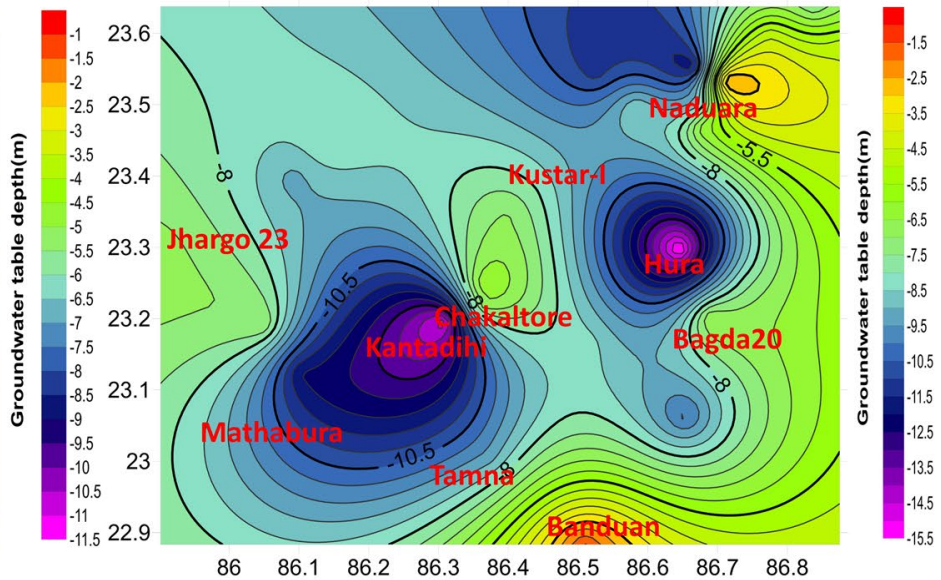

$2 b$

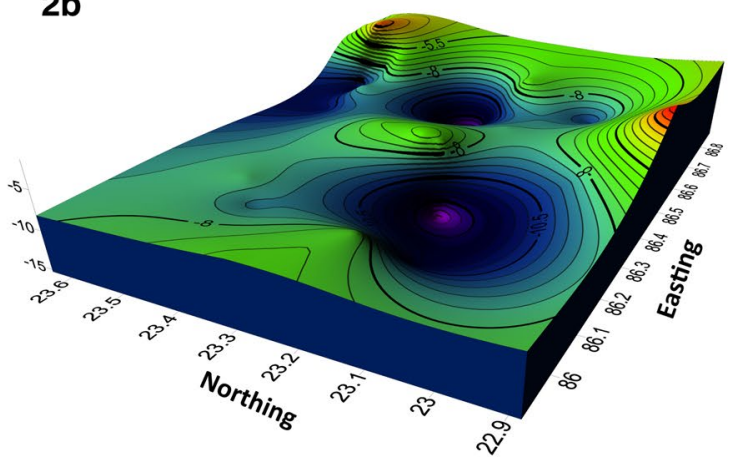

Fig. 10 Illustration of future water depression zones (2040) over Purulia district, 1.a. Post monsoon 1.b. Pre monsoon 2.a. 3d representation of post monsoon groundwater level $\mathbf{2 . b .} 3 \mathrm{~d}$ representation of pre monsoon groundwater level

in the unconfined aquifer system. iii. The huge anthropogenic pressure such as over exploitation and unscientific uses of groundwater are other significant reasons behind groundwater variability. Anthropogenic influences can contaminate the quality and reduce the level of groundwater table by agricultural and industrial activities (Huang et al. 2013). Groundwater is mainly recharged by the rainfall. Subsequently, periodic variation or change of rainfall quantity and pattern can affect the concentration level of groundwater. The lower level of rainfall can cause the groundwater level depletion in an unconfined aquifer system.

\section{Conclusion}

The present study attempts to illustrate the seasonal fluctuation pattern of groundwater table and demarcates the trend of groundwater change through different geospatial techniques and statistical nonparametric analysis. The Mann-Kendall with Sen's slope estimator reveals that a major portion of Purulia district (extended part of Chota Nagpur Plateau) has been observed a significant declining trend of groundwater table in both periodic times (post- and pre-monsoon). The pre- and post-monsoon results (1996-2017) displayed that around 77\% (22 stations) and $78 \%$ (23) monitoring stations were significantly declining trend of groundwater table at the rate of -0.006 to $-0.205 \mathrm{~m} /$ year and -0.005 to $-0.192 \mathrm{~m} /$ year, respectively. The future prediction indicates that there is high probability of groundwater depression in different pockets and this area is also experienced by recurring groundwater drought. This scientific study revealed that steady decline of groundwater table is due to unscientific withdrawal of groundwater and land use modification may obstruct the natural recharge of groundwater. The study showed that the land use patterns have been tremendously changed in this semi-arid region. Now, farmers are using massive groundwater for pre- and post-monsoon crop cultivation. The study focused that the entire region is being faced severe water scarcity problem particularly during premonsoon season. So, sustainable water resource management is highly essential for regional development of this region. Artificial and natural aquifer recharge, rainwater harvesting, continuous monitoring of groundwater fluctuation level and integrated watershed management are suitable sustainable management techniques to improve 
the groundwater table in the unconfined and semi confined aquifer of an extended part of Chota Nagpur Plateau Region.

Funding The author(s) received no specific funding for this work.

\section{Declaration}

Conflict of interest The authors declare that they have no known competing financial interests or personal relationships that could have appeared to influence the work reported in this paper.

Ethical approval All authors certify that the research is conducted ethically.

Open Access This article is licensed under a Creative Commons Attribution 4.0 International License, which permits use, sharing, adaptation, distribution and reproduction in any medium or format, as long as you give appropriate credit to the original author(s) and the source, provide a link to the Creative Commons licence, and indicate if changes were made. The images or other third party material in this article are included in the article's Creative Commons licence, unless indicated otherwise in a credit line to the material. If material is not included in the article's Creative Commons licence and your intended use is not permitted by statutory regulation or exceeds the permitted use, you will need to obtain permission directly from the copyright holder. To view a copy of this licence, visit http://creativecommons.org/licenses/by/4.0/.

\section{References}

Acharya T, Prasad R (2017) Lithostratigraphic contact-a significant site for hydrogeological investigation in crystalline fracturedrock terrains. J Earth Syst Sci 126(1). https://doi.org/10.1007/ s12040-016-0784-9

Adhikary PP, Chandrasekharan H, Chakraborty D et al (2010) Assessment of groundwater pollution in West Delhi, India using geostatistical approach. Environ Monit Assess 167:599-615. https://doi.org/10.1007/s10661-009-1076-5

Assaf H, Saadeh M (2009) Geostatistical assessment of groundwater nitrate contamination with reflection on DRASTIC vulnerability assessment: the case of the upper Litani Basin. Lebanon Water Resour Manag 23(4):775-796

Babiker M, Gudmundsson A (2004) The effects of dykes and faults on groundwater flow in an arid land: the Red Sea Hills. Sudan J Hydrol 297(1-4):256-273. https://doi.org/10.1016/j.jhydrol. 2004.04.018

Basu SR, Bera B (2010) Jalobigyan (Text Book of Hydrology). https://www.researchgate.net/publication/327578595_Jalob igyan_Text_Book_of_Hydrology (access date (April, 2021).

Bera B (2010) Ground water potential zones in the hardrock area, applying RS, GIS \& ERS Techniques, Gangtok. Sikkim Himalayas Geographical Rev India 72(2):170-180

Bera B, Ghosh A (2019) Fluoride dynamics in hydrogeological diversity and Fluoride Contamination Index mapping: a correlation study of North Singbhum Craton. India Arab J Geosci 12(24):802. https://doi.org/10.1007/s12517-019-4994-8

Bera B, Bhattacharjee S, Ghosh A, Ghosh S, Chamling M (2019) Dynamic of channel potholes on Precambrian geological sites of Chhota Nagpur plateau, Indian peninsula: applying fluviohydrological and geospatial techniques. SN Appl Sci 1(5):494. https://doi.org/10.1007/s42452-019-0516-2
Bera B, Bhattacharjee S, Chamling M, Ghosh A, Sengupta N (2021b) Fluoride hazard and risk enumeration of hard rock unconfined aquifers in the extended part of Chhota Nagpur Gneissic Complex. J Geolo Soci India 97:199-209. https://doi.org/10.1007/ s12594-021-1651-0

Bera B, Shit PK, Sengupta N, Saha S, Bhattacharjee S (2021e) Trends and variability of drought in the extended part of Chhota Nagpur plateau (Singbhum Protocontinent), India applying SPI and SPEI indices. Environ Challenges 5:100310. https://doi.org/ 10.1016/j.envc.2021.100310

Bera B Bhattacharjee S, Chamling M, Ghosh A, Sengutpa N, Ghosh S (2021c) Relationship between diameter and depth of potholes controlled by lithology and structure in the Rarh region of India. Curr Sci 121:697-703. https://doi.org/10.18520/cs/v121/i5/697-703

Bera B, Bhattacharjee S, Chamling M, Ghosh A, Sengupta N, Ghosh S (2021e) Fluoride dynamics in precambrian hard rock Terrain of North Singhbhum Craton and effect of fluorosis on human health and society. Groundwater Soc, pp 319-348. https://doi.org/10. 1007/978-3-030-64136-8_15.

Bera B, Bhattacharjee S, Chamling M, Ghosh A, Sengutpa N, Ghosh S (2021d) High fluoride in groundwater and fluorosis related health hazard in Rarh Bengal, India: a socio-environmental study. Curr Sci 120:1225-1233. https://doi.org/10.18520/cs/v120/i7/ 1225-1233

Bhattacharya S (1989) Ductile shear zone in Purulia. West Bengal Indian J Geol 61(3):172-178

Bhattacharya PK, Mukherjee S (1987) Granulites in and around the Bengal anorthosite, eastern India; genesis of coronal garnet, and evolution of the granulite-anorthosite complex. Geol Mag 12:2132. https://doi.org/10.1017/S0016756800015752

Bloomfield JP, Marchant BP (2013) Analysis of groundwater drought using variant of Standardised Precipitation Index. Hydrol Earth Syst Sci Dis 10(6):7537-7574. https://doi.org/10.5194/ hessd-10-7537-2013

Burgess TM, Webster R (1980) Optimal interpolation and isarithmic mapping of soil properties. I: The semivariogram and punctual kriging. Eur J Soil Sci 31(2):315-331.

CGWB (Central Ground Water Board) (2017-2018) Ministry of Water Resources, River Development and Ganga Rejuvenation, Government of India (2017-2018) Ground Water Year Book-India, pp 2017-2018.

CGWB (2011) Dynamic Ground Water Resources of India (as on 31 March 2009). Central Ground Water Board (CGWB), Ministry of Water Resources, Government of India, New Delhi, p 243

Chakraborty B, Roy S, Bera A, Adhikary PP, Bera B, Sengupta D, Bhunia G, Shit P (2021) Geospatial assessment of groundwater quality for drinking through water quality index and human health risk index in an upland area of Chota Nagpur Plateau of West Bengal, India. spatial modeling and assessment of environmental contaminants 19 pp. 327-358 Publisher Springer, Cham, https:// doi.org/10.1007/978-3-030-63422-3_19.

Chatterjee R, Samadder S, Mondal D, Adhikary K (2020) Analysis of spatio-temporal trend in groundwater elevation data from arsenic affected alluvial aquifers - case study from Murshidabad district, West Bengal. Eastern India J Earth Syst Sci 129:228. https://doi. org/10.1007/s12040-020-01489-8

Cook PG (2003) A guide to regional groundwater flow in fractured rock aquifers; CSIRO Land and Water, Australia.

CWC (Central Water Commission) (2006) Water and related statistics. New Delhi, India: Central Water Commission, Ministry of Water Resources, Government of India

Doll P, Hoffmaan-Dobrev H, Portmann FT, Siebert S (2012) Impact of water withdrawals from groundwater and surface water on continental water storage variations. J Geodyn 59:143-156. https:// doi.org/10.1016/j.jog.2011.05.001 
Dolui G, Chatterjee S, Das Chatterjee N (2014) Weathering and mineralogical alteration of granitic rocks in Southern Purulia District, West Bengal, India. Int Res J Earth Sci 2:1-12

Dunn JA, Dey AK (1942) The geology and petrology of eastern Singhbhum and surroundings areas. Mem. Geol Surv Ind 69(2).

Gehrels JC, Van Geer FC, de Vries JJ (1994) Decomposition of groundwater level fluctuations using transfer modeling in an area with shallow to deep unsaturated zones. J Hydrol 157:105138. https://doi.org/10.1016/0022-1694\%2894\%2990101-5

Ghosh NC, Chatterjee N, Mukherjee D, Kent RW, Saunders AD (2008) Mineralogy and geochemistry of the Bengal Anorthosite Massif in the Chhotanagpur Gneissic Complex at the Eastern Indian Shield Margin. J Geolo Soci India 72:63-277

Gun JVD (2012) Groundwater and global change: trends, opportunities and challenges; France. International Hydrological Programme.

Halder S, Roy MB, Roy PK (2020) Analysis of groundwater level trend and groundwater drought using Standard Groundwater Level Index: a case study of an eastern river basin of West Bengal India. SN Appl Sci 2:507. https://doi.org/10.1007/ s42452-020-2302-6

Hanson RT, Newhouse MW, Dettinger MD (2004) A methodology to assess relations between climatic variability and variations in hydrologic time series in the southwestern United States. J Hydro 287(1-4):252-269. https://doi.org/10.1016/j.jhydrol.2003.10.006

Huang G, Sun J, Zhang Y, Chen Z, Liu F (2013) Impact of anthropogenic and natural processes on the evolution of groundwater chemistry in a rapidly urbanized coastal area, South China. Sci Total Environ 463-464:209-221. https://doi.org/10.1016/j.scito tenv.2013.05.078

Hyndman RJ, Koehler AB, Ord JK, Snyder RD (2008) Forecasting with exponential smoothing: the state space approach. Springer, Heidelberg

Kendall MG (1975) Rank correlation methods, 4th edn. Grif Bn, London

Khorasani M, Ehteshami M, Ghadimi H, Salari M (2016) Simulation and analysis of temporal changes of groundwater depth using time series modeling. Model Earth Syst Environ 2:90. https://doi.org/ 10.1007/s40808-016-0164-0

Krogulec E (2018) Evaluating the risk of groundwater drought in groundwater-dependent ecosystems in the central part of the Vistula River Valley. Poland Ecohydrol Hydrobiol 18(1):82-91. https://doi.org/10.1016/j.ecohyd.2017.11.003

Li F, Feng P, Zhang W, Zhang T (2013) An integrated groundwater management mode based on control indexes of groundwater quantity and level. Water Resour Manag 27(9):3273-3292. https://doi. org/10.1007/s11269-013-0346-8

Li X, Li G, Zhang Y (2014) Identifying major factors affecting groundwater change in the North China Plain with grey relational analysis. Water 6:1581-1600. https://doi.org/10.3390/w6061581

Machiwal D, Singh PK (2015) Understanding factors influencing groundwater levels in hard-rock aquifer systems by using multivariate statistical techniques. Environ Earth Sci 74:5639-5652. https://doi.org/10.1007/s12665-015-4578-1

Mahadevan TM (1992) Geological evolution of the Chotanagpur Gneiss Complex in a part of Purulia district, West Bengal. Indian J Geol 64:1-22

Mahadevan, TM (2002) Geology of Bihar and Jharkhand. Geol Soci India Bangalore 563.

Mantegna RN, Stanley HE (2000) An introduction to econophysics: correlations and complexity in finance. Cambridge University Press, Cambridge

McClaran MP, Wei H (2014) Recent drought phase in a 73-year record at two spatial scales: implications for livestock production on rangelands in the Southwestern United States. Agric Forest Meteorol 197:40-51. https://doi.org/10.1016/j.agrformet.2014.06.004
Mckee TB, Doesken NJ, Kleist J (1993) The relationship of drought frequency and duration to time scales, preprints. In: Proceedings of the 8th conference on applied climatology, Anaheim, CA, USA, 17-22 January 1993; pp. 179-184.

Mgandu FA, Mkandawile M, Rashid M (2020) Trend analysis and forecasting of water level in Mtera Dam using exponential smoothing. Int J Math Sci Comput 6:26-34. https://doi.org/10.5815/ijmsc. 2020.04.03

Mini PK, Singh DK, Sarangi A (2014) Spatio-temporal variability analysis of groundwater level in coastal aquifers using geostatistics. Int J Environ Res Dev 4(4):329-336

Mondal A, Kundu S, Mukhopadhyay A (2012) Rainfall trend analysis by Mann-Kendall test: A case study of northeastern part of the Cuttack District Orissa. Int J Geol Earth Environ Sci 2(1):70-78

Nam JE, Lee YH, Jung KY (2012) Analysis of evapotranspiration effect on drought by comparison of SPI and SPEI Drought indices. In: Proceedings of the Autumn Meeting of KMS, Daegu, Korea; pp. 390-391. (In Korean).

Nayak S, Mukhopadhyay B, Mitra A, Chakraborty R (2020) Structural control on the occurrence of groundwater in granite gneissic terrain, Purulia. West Bengal Arab J Geosci 13:955. https://doi.org/ 10.1007/s12517-020-05853-2

Nazari Zade F, Arshadiyan F, Zand-Vakily K (2006) Study of spatial variability of groundwater quality of Balarood Plain in Khuzestan Province. The first congress of optimized exploitation from water source of Karoon and Zayanderood Plain. Shahre kord University, pp. 1236-1240.

Nilsen KH, Sydnes M, Gudmundsson A, Larsen BT (2003) How dykes affect groundwater transport in the northern part of the Oslo Graben. EGS-AGU-EUG Joint Assembly.

Pan Y, Gong H, Zhou D, Li X, Nakagoshi N (2011) Impact of land use on groundwater recharge in Guishui River Basin. China Chinese Geogr Sci 21:734. https://doi.org/10.1007/s11769-011-0508-7

Pascoe ED (1973) A manual of geology of India and Burma, vol. 1. Geological Survey of India, Calcutta, 1973, 485p.

Pathak AA, Dodamani BM (2019) Trend analysis of groundwater levels and assessment of regional groundwater drought: Ghataprabha River Basin. India Nat Resour Res 28(3):631-643. https://doi.org/ 10.1007/s11053-018-9417-0

Pophare AM, Lamsoge BR, Katpatal YB, Nawale VP (2014) Impact of over-exploitation on groundwater quality: a case study from WR-2 Watershed. India J Earth Syst Sci 123(7):1541-1566. https://doi. org/10.1007/s 12040-014-0478-0

Rasel HM, Alam S, Hasnat A, Hossain I, Hasan M, Ahsan A (2019) Geospatial analysis of groundwater level variations using Kriging Method. J Eng Appl Sci 3(2):21-34

Razali SNAM, Rusiman MS, Zawawi NI, Arbin N (2018) Forecasting of water consumptions expenditure using Holt-Winter's and ARIMA. J Phys Conf Series 995(1):012041. https://doi.org/10. 1088/1742-6596/995/1/012041

Roy AB (2012) Indian Shield: insight into the pristine size, shape and tectonic framework. Indian J Geosci 66:181-192

Roy A (2014) Availability, scarcity and potentiality of groundwater resources in Puruliya District of West Bengal: an appraisal. Int J Scientific Footprints 2(1):78-93

Roy AB, Dutt K, Rathore S (2016) Development of ductile shear zones during diapiric magmatism of nepheline syenite and exhumation of granulites, examples from central Rajasthan, India. Curr. Sci. 110:1094-1101. https://doi.org/10.18520/cs/v110/i6/1094-1101

Russo TA, Lall U (2017) Depletion and response of deep groundwater to climate-induced pumping variability. Nat Geosci 10(2):105108. https://doi.org/10.1038/ngeo2883

Sakizadeh M, Mohamed MMA, Klammler H (2019) Trend analysis and spatial prediction of groundwater levels using time series forecasting and a novel spatio-temporal method. Water Resour Manage 33:1425-1437. https://doi.org/10.1007/s11269-019-02208-9 
Saraf AK, Choudhury PR (1998) Integrated remote sensing and GIS for groundwater exploration and identification of artificial recharge sites. Int J Remote Sens 19(10):1825-1841. https://doi.org/10. 1080/014311698215018

Saxena VP, Krishnamurthy P, Murugan C, Sabot HK (1992) Geochemistry of the granitoids from the central Surguja shear zone, India: geological evolution and implication on uranium mineralization and exploration. Exploration and Research for Atomic Minerals 5:27-40

Sen PK (1968) Estimates of the regression coefficient based on Kendall's tau. J Am Stat Assoc 63(324):1379-1389

Thakur GS, Thomas T (2011) Analysis of groundwater levels for detection of trend in Sagar District, Madhya Pradesh. J Geol Soci India 77:303-308. https://doi.org/10.1007/s12594-011-0038-z
Yang D, Li C, Hu H, Lei Z, Yang S, Kusuda T, Koike T, Musike K (2004) Analysis of water resources variability in the Yellow river of China during the last half century using their historical data. Water Resour Res 40(6):1-12. https://doi.org/10.1029/2003W R002763

Zhou ZM, Zhang GH, Wang JZ, Yan MJ (2011) Risk assessment of soil salinity by multiple-variable indicator kriging in the low plain around the Bohai Sea. J Hydraul Eng 42(10):1144-1151

Publisher's Note Springer Nature remains neutral with regard to jurisdictional claims in published maps and institutional affiliations. 